\title{
Отечественное детское телевидение: к вопросу ретроспективной периодизации
}

\author{
Ключевская О.С. \\ LikeMe Studio, \\ Россия, 191119, г. Санкт-Петербург, ул. Марата, д. 86 \\ E-mail: exsell@mail.ru
}

\begin{abstract}
Аннотация. Изменяющиеся информационно-технические условия в медиасреде усилили воздействие телевизионного и детского контента на подрастающее поколение. В современном научном дискурсе анализ исторического прошлого детского российского телевидения недостаточно представлен, в то время как изучение отечественного контента для детей в ретроспективе может способствовать осознанию проблем функционирования современного детского российского телевидения, а значит, и поиску способов совершенствования организации и содержания передач для детей, что и является целью данного исследования. Путем теоретического и сравнительного анализа, по-новому рассматрены этапы и периоды детского телевидения в разные годы (выявлены основные расхождения, сходства и взаимосвязи). Определены два основных этапа отечественного детского телевидения, которые подразделяются на периоды: 1) советский этап - появление и развитие советского детского вещания в СССР: зарождение (с 1939 по 1954)); создание системы советского детского вещания (1954-1970); подъем советского детского кинематографа и передач для детей (с 1970 г. до середины 1980-х гг.); перестроечный период (1985-1987) и 2) постсоветский этап (становление российского детского ТВ): период острого кризиса в детском телевещании (с 1987 по 1997г.); период интервенции западных телеканалов (1998 по 2005); начало реабилитации отечественного детского ТВ (с 2005 по 2010 гг.) 4) период- функционирования государственного федерального российского детского ТВ (с 2010 года по настоящее время).
\end{abstract}

Ключевые слова: телеканалы для детей, периодизация, советское детское телевещание, ТВ для детей в постсоветской России.

Для цитирования: Ключевская О.С. 2020. Отечественное детское телевидение: к вопросу ретроспективной периодизации. Вопросы журналистики, педагогики, языкознания, 39 (3): $331-$ 344. DOI 10.18413/2712-7451-2020-39-3-331-344

\section{Retrospective periodization of domestic children's television}

\author{
Olesya S. Kyuchevskaya \\ LikeMe Studio, \\ Russia, 191119, St. Petersburg, st. Marata, 86 \\ E-mail: exsell@mail.ru
}

Annotation. Changing information and technical conditions in the media environment have increased the impact of television and children's content on the younger generation. In modern scientific discourse, the analysis of the historical past of children's Russian television is insufficiently presented, while the study of domestic content for children in retrospect can contribute to understanding the problems of functioning of modern children's Russian television, and therefore to finding ways to improve the organization and content of programs for children, which is the purpose of this study. Through theoretical and comparative analysis, the stages and periods of children's television in different years are reviewed in 
a new way (the main differences, similarities and relationships are identified). Two main stages of domestic children's television vision are defined, which are divided into periods: 1) the Soviet stage - the emergence and development of Soviet children's broadcasting in the USSR: the birth (from 1939 to 1954)); the creation of the Soviet children's broadcasting system (1954-1970); the rise of Soviet children's cinema and programs for children (from 1970 to the mid-1980s); perestroika period (1985-1987) and 2) post-Soviet stage (formation of Russian children's TV): the period of acute crisis in children's television broadcasting (from 1987 to 1997); the period of intervention of Western TV channels (1998 to 2005); the beginning of rehabilitation of domestic children's TV (from 2005 to 2010) 4) the period of functioning of the state Federal Russian children's TV (from 2010 to the present).

Keywords: children's channels, periodization, Soviet children's television. children's TV in Russia, stages of children's television.

For citation: Kyuchevskaya O.S. 2020. Children's television in Russia: on the issue of retrospective periodization. Issues in Journalism, Education, Linguistics, 39 (3): 331-344 (in Russian). DOI 10.18413/2712-7451-2020-39-3-331-344

\section{Введение}

Детское телевидение и предназначенный для детей медиаконтент за последние 30 лет претерпели радикальные изменения в российской медиасреде. Информационное детское пространство стало неотъемлемой составляющей мирового глобализированного информационного рынка. Дети - самая многочисленная и самая медийная часть социума (произошел заметный рост доли просмотров видео на мобильных устройствах ${ }^{1}$. Интернет, телевещание и масс-медиа усилили свое влияние на детство, являясь основными институтами социализации детй в современном мире. Все больший спрос набирает контент для детей. При этом надо отметить, что ценностные ориентиры детского медиаконтента более двух десятилетий формируются под влиянием западной информационной продукции и культуры. Опыт и традиции советского детского кинематографа и телевещания, к сожалению, забыт.

Вместе с тем растет запрос общества на изучение прошлого и настоящего российского детского телевидения и медиаконтента для детей на современном этапе информационной трансформации. На научных конференциях и открытых столах специалисты в сфере журналистики все чаще ставят на повестку дня темы детского телевидения ${ }^{2}$. Государство также проявляет интерес к данному вопросу. Так Минобрнауки намеревалось организовать детское телевидение во всех школах ${ }^{3} \Phi^{3}$. Родители тоже проявляют активность, например, на канале «Научи хорошему» критикуют современный детский контент для детей и хвалят советский. Таким образом, вопросы искоренения негативных влияний медиасреды на детей и создание качественного телевизионного контента для воспитания нравственно и духовно здорового подрастающего поколения россиян становятся все более актуальны.

В связи с вышесказанным необходимо проанализировать исторический путь создания детского телевизионного контента и выделить периоды его развития, чтобы макси-

1 Дети медиапотребление. 2017. Отчет MOMRI http://cyberpsy.ru/articles/children _media_2017_momri/

${ }^{2}$ Вторая научно-практическая конференция Москва, ул. Моховая, 9 Факультет журналистики МГУ имени М. В. Ломоносова. Учимся говорить по-русски. Проблемы современного языка в электронных СМИ. Программа 27-28 сентября 2017 года. http://www.journ.msu.ru/downloads /2017/Программа\%20конференции.pdf

3 Минобрнауки намерено организовать детское телевидение во всех школах. https://tass.ru/obschestvo/4411952 
мально учесть накопленный в нашей стране опыт создания для российской детской аудитории телепередач, социализирующих, а также развивающих детей нравственно и духовно. Важно обратить внимание на телевизионный контент как на средство воспитания нравственно и физически здорового поколения граждан страны.

Теоретическую основу составляют научные публикации авторов из разных областей. Кризис детского телевидения, а также негативное влияние коммерции отмечали исследователи И. Аношина [2003] и А. Короченский [2003]. Усвоение личностных ценностей, социальных норм, правил поведения под влиянием экранной культуры рассматривали социологи Шариков, Чудинова [2007]. Вопросы производства программ для детей в разных странах анализирует О. Маховская [2017]. Функционирование телевидения в контексте политических и социальных реалий современного российского государства рассматривалось в работах таких авторов, как А. Качкаева [2000], С. Ильченко [2009], В. Цвик [2017] и др., однако указанные авторы не акцентировали своё внимание на проблематике истории детского телевещания. Несмотря на растущую в последние годы популярность детского телевидения и медиаконтента, практически отсутствуют системные исследования данной проблематики, включая периодизацию развития детского телевидения и телеканалов для детей, изучения специфики каждого из периодов. В российских научных кругах принято рассматривать отдельные проблемы в рамках определенных исторических моментов. В итоге наблюдается игнорирование основ и традиций общей и непрерывной истории отечественного детского телевидения.

Целью данного исследования является ретроспективный анализ детских телеканалов и другого медиаконтента для детей с советских времен и по настоящее время для выявления их основных временных периодов развития и ключевых сущностных характеристик. Путем теоретического и сравнительного анализа рассмотрены этапы и периоды детского телевидения в разные годы (выявляются основные расхождения, сходства и взаимосвязи). Гипотезой исследования является предположение о том, что, несмотря на очевидную разницу в советском телевещании для детей и современном детском российском телевидении, сегодня заслуживают внимания сильные стороны советского детского телевещания, накопленный в ту эпоху позитивный опыт, который должен быть учтён и применен российскими вещателями и создателями телепередач для детей.

Объектом анализа стали трансформация миссии отечественного детского телевидения, содержания передач для детей, специфики организации и экономической базы телевещания для детской аудитории. Эмпирической базой работы являются правовые и служебные документы, относящиеся к телевещанию для детей, а также телепередачи для детей. Исследование проводилось на основе дискурсивного анализа, контент-анализа медийного содержания детского ТВ на разных этапах развития, а также теоретического и сравнительного анализа.

Для изучения проблемы был проведен анализ отечественного телевизионного и медиаконтента в ретроспекции и изучены исследования по данной темы.

\section{Качественные этапы отечественного телевидения}

Детское отечественное телевидение отличается особой историей экспериментами, находками и заимствованиями, производственными взлетами и падениями, а также подверженностью идеологическим и глобализационным влияниям.

М. Мыгаль, говорит «о трех этапах в истории развития детского телевидения: советском (1939-1990 гг.), переходном (1990-1994 гг.) и новейшем (с 1994 года)» [Мыгаль, 2014a, с. 209]. 
На наш взгляд, отечественное телевидение для детей прошло два основных контрастных этапа: советский и постсоветский, которые в свою очередь разбиваются на отдельные периоды. Переходный период продлился недолго, и его хронологические границы размыты, поэтому лучше ограничится обозначением двух этапов, а переходный рассматривать как период, обозначивший начало постсоветского этапа. Поэтому более обоснованным является выделение двух контрастных этапов:

1) советский этап или советское детское телевещание (1939-1990-е годы);

2) постсоветский период или российское ТВ для детей (1990-2020-е годы).

Для характеристики советского периода становления и развития детского телевидения, на наш взгляд, наиболее подходит определение термина «детское телевещание», данное В. Егоровым в «Терминологическом словаре телевидения: основные понятия и комментарии» [Егоров, 1997]. Данный термин относится к передачам, предназначенным для детской аудитории, поскольку в СССР не было специализированных каналов для детей разного возраста, а выходили отдельные передачи в сетке вещания центральных каналов, и не существовало универсального детского специализированного телеканала для аудитории разного возраста [Мыгаль, 2014б, с. 208]. Стоит отметить высокую концентрацию нравственности и иделогизации этого контента.

Для постсоветского этапа применим термин «российское ТВ для детей», поскольку в эфире современной России появляются наряду с детскими передачами на «взрослых» каналах отдельные, полностью специализированные детские телеканалы, вначале зарубежные, например, Cartoon Network, Nickelodeon, затем отечественные, например, «Детский мир» (1996 г., первый отечественный детский телеканал на российской спутниковой DTH-платформе «НТВ-Плюс»).

\section{Периодизация советского телевещания для детей}

Советское руководство страны учитывало важность информационного посыла для воспитания поколений советских детей через радио, кино и телевещание. Так, детское кино названо исследователем А.Я. Холод «важным средством учебно-воспитательного процесса в конце 20-х - начале 30-х годов XX века» [Холод, 2017, с. 35]. Были предприняты попытки применить научные подходы к воспитанию и информационной работе с поколениями советских детей, к кино- и телепроизводству привлекались в качестве консультантов педагоги и врачи. Были написаны критические статьи и разработаны научные подходы для создания специализированного воспитывающего советского контента. Это заложило основы отечественного медиаобразования [Федоров, Челышева, 2002].

Основы создания детских образовательных и развлекательных передач были заложены на протяжении советского этапа детского телевещания - с 1939 по 1990 год. Созданные на советском ТВ передачи для детей, например, «АБВГДейка», «Спокойной ночи, малыши», «Ералаш», изменившись, транслируются и в настоящее время. Многие телеканалы до сих пор транслируют советское детское кино и анимацию, которые занимали существенную часть телепоказа для детей в СССР.

На формировании советского детского вещания сказалась теория, основанная на первых исследованиях А. Бандуры (в 1927 году). Считалось, что кино и ТВ мощно способствуют «социальному научению». В ходе просмотра передач дети и наблюдают, и копируют социальное поведение взрослых «по типу научения у животных», что использовалось в телепрограммах для детей [Маховская, 2017, с. 19].

Однако с появлением кино- и телепередач возникла и проблема негативного воздействия телевидения на детей. Велась работа по нейтрализации негативного влияния на психическое здоровье телезрителей и усилению идеологических и нравственных тенден- 
ций воспитания советского человека. Также разрабатывалась специфика освещения многих аспектов проблем детской кинокритики, выявленная на основе материалов комиссии изучения ребенка-зрителя [Холод, 2017, с. 35].

Исследователь А. Холод, рассматривает информационные материалы «Киногазеты» за 1929 год, где публиковалось множество критических статьей того времени, в том числе и очерки «Детские акулы». В текстах газетных статей актуализировались проблемы здоровья молодого поколения и фиксировались негативные влияния, также затрагивалась проблема отсутствия фильмов, предназначенных специально для детей, и проводилась параллель «восприятие информации - потребление пищи» [Холод, 2017, с. 36]. Часть газетных публикаций была посвящена изучению восприятия детей.

Генеральная цель (миссия) программ советского ТВ для детей заключалась во всестороннем воспитании и образовании детей разного возраста. На советское детское телевидение возлагалась особая «миссия социализатора, воспитателя и педагога» [Мыгаль, 2014б, с. 223]. Современные исследователи нередко акцентируют идеологическое предназначение телевещания для советских детей, однако содержание телепередач свидетельствует о том, что социализирующее, развивающее их предназначения явно преобладали над идеологическими элементами.

Советский этап развития телевещания для детей отличался жанрово-тематическим разнообразием передач, ориентированных на разновозрастную детскую аудиторию. Выработанная миссия детского советского телевещания предполагала уделять особое внимание формированию с помощью программ трудовых навыков, инициативы, самостоятельности, любознательности детей, вовлечению их в разнообразные дела, в коллективы юных техников, натуралистов, спортсменов [Холод, 2017, с. 45].

Психологическому анализу телевидения предшествовали попытки создать психологическую теорию его влияния на зрителей: это попытались сделать в 20-е годы П.И. Люблинский, в 30-е - О.И. Никифоров [Маховская, 2017, с. 34]. Следуя рекомендациям учёных, советское телевещание изначально предлагало программы для совместного семейного просмотра (детей и взрослых).

В довоенное время проходят первые трансляции специализированных радиопередач для детей. Обобщив опыт радиовещания, телевидение создает собственные программы, положив начало зарождению детского вещания. Этому способствовало широкое распространение средств массовой информации как «воспитателя» советского общества.

Первая детская телепередача «С новым годом» вышла в январе 1939 года. В это время были заложены основы образовательных и развлекательных передач. Первоначально в детском телевещании доминировали спектакли, анимационные и художественные фильмы, но детских оригинальных передач было крайне мало. В частности, это было связано с незавершенностью в целом экспериментального состояния нарождавшегося советского телевещания, которое сохранялось до второй половины 1950-х гг.

Первые передачи для детей выходили в прямом эфире и рассчитывались на разновозрастную детскую аудиторию и совместный просмотр передач детьми и взрослыми. Несмотря на недостатки первых трансляций - технические неполадки со звуком и изображением - советский контент отличался жанрово-тематическим разнообразием и ценностносмысловым содержанием передач. Постепенно выделяются жанры: спортивные, музыкальные, художественно-изобразительные, научно-популярные, патриотические и др.

С 1954 г. советское государство уделяло большое внимание телевидению как источнику информации, которое должно было соответствовать высоким требованиям и стандартам общества. Вступая в новый, более зрелый период своего развития, телевидение становится одним из агентов воспитания и социализации молодого поколения. Была 
определена основная тематика телевизионных передач: детские и юношеские программы о пионерах, военно-патриотические, спортивные, научно-популярные программы. Большое внимание уделялось художественно эстетическому воспитанию новых поколений [Мыгаль, 2014б, с. 210]. Как и советское ТВ в целом, вещание для детей было подчинено идеологическим императивам советского строя.

Стоит обратить внимание на воспитательно-познавательные передачи советского телевещания для детей - «АБВГДейка» (создана по формату американского проекта «Улица Сезам»), «Хочу все знать». Необходимо отметить также детское художественное кино и уникальную школу советской анимации для детей. В этот период телевещание для детей, получившее в своё распоряжение современные технические ресурсы, достаточное финансирование и творческие ресурсы, в наибольшей мере соответствовало миссии социализатора, воспитателя и педагога. Отметим, что существенное значение имели научные и практические подходы к решениям проблем советского телевещания для детей. Важно отметить как достигнутый результат высокое воспитательное качество советского детского телеконтента. Передачи транслировали комплекс ценностей взаимопомощи и солидарности, уважения к человеку и созидательному труду.

Под влиянием перемен периода перестройки к началу 1990-х годов на ТВ снизилась активность вещания программ для школьников и дошкольников. Эти перемены были связаны с реформами и политикой руководства страны [Мыгаль, 2014б, с. 219]. На финише советского телевещания начиналось расформирование единой системы телевещания для детей, детские редакции получили автономию, возникла конкуренция между ними. Началось интенсивное внедрение импортной продукции на ТВ с целью развлечения аудитории.

Произошло смещение внимания создателей детских передач с младшей и средневозрастной зрительской аудитории на подростковую. А.М. Грачева, В.С. Собкин, М.В. Хлебникова полагают, что в «70-80 гг. телеэкран „центрировал" подростковую культуру» [Собкин и др., 2000]. Иными словами, в той культуре были «телевизионные ядра», которые определяли общественное мнение и ценностные ориентации подростковой культуры. Телепередачи «Мир и молодежь», «До 16 и старше», «Взгляд», «12 этаж» и другие собирали у экранов немало подростков и молодежи [Шариков, Чудинова, 2007, с. 82].

Большое влияние на советских подростков и тинейджеров до начала 90-х имели ведущие, такие как Сергей Супонев, Георгий Галустян и Леся Башева, которые, являясь взрослыми, смогли стать «своими» для них. Необходимо отметить появление адресованных подросткам популярных программ, выходивших на центральном телевидении до начала 1990-х «До 16 и старше», а затем и «Марафон 15». В последующие годы такие передачи создать не получится. В итоге советский этап детского телевещания отличался жанрово-тематическим разнообразием передач, ориентированных на разновозрастную детскую аудиторию.

Таким образом, развитие советского детского телевиденья прошло несколько периодов:

1) Период зарождения советского детского телевещания (1939-1954 гг.). На советском телевидении формировались основы передач для детей. Первыми в детском вещании транслировались спектакли, анимационные и художественные фильмы, но их было мало.

2) Период создания системы советского детского вещания (с 1954 по 1970 гг.). Произошло оформление устойчивого набора телепередач для детей. На основе опыта детских СМИ (печатной и детской радиожурналистики) телевидение создало свое детское направление с особенностями, характерными для аудиовизуальных массмедиа. В те годы началась систематизация детского контента, а также создание своеобразных собственных советских детских передач. 
В последующие годы всё более отчётливо реализуется миссия советского детского телевещания. В программах особое внимание уделяется развитию трудовых навыков, инициативы, самостоятельности, любознательности детей, вовлечению их в разнообразные общественно-полезные дела, в коллективы юных техников, натуралистов, спортсменов». Основная тематика телевизионных передач: программы о пионерах, военнопатриотическом воспитании, научно-популярные и иные познавательные программы, спортивные, а также передачи, имевшие целью художественно-эстетическое воспитание. Постепенно увеличивалось количество передач, появились программы, аналогичные зарубежным, например, «Спокойной ночи, малыши», «Будильник» и др.

3) Период подъема советского детского кинематографа и телепередач для детей (с 1970 г. до середины 1980-х гг.) стал наиболее плодотворным и примечательным временем в советском телевещании. За предыдущие периоды был накоплен значительный опыт, улучшилось техническое оснащение, телевидение стало доступнее для населения. Все эти факторы способствовали подъему детского телевещания. Расширился список жанров и тем, охватывающих детское направление. Популярны у детской аудитории передачи «АБВГДейка», «В гостях у сказки», «Ералаш» и др.

4) Последний, «перестроечный», период советского телевещания для тетей (с 1985 по 1987 гг.) характеризуется снижением активности трансляции программ детского направления, переключением преимущественно на подростковую аудиторию.

\section{Постсоветский этап развития российского детского телевидения}

Под влиянием общественно-политических и экономических перемен в начале 1990-х годов на российском телевидении существенно снизилось количество передач для школьников и дошкольников и качественный уровень детской телепродукции. Под влиянием коммерциализации телевидения и отказа от прежних идеологических и ценностных установок радикально изменилась миссия телевидения, включая и вещание на детскую аудиторию. В условиях рынка экономическая функция стала приоритетной по отношению к другим функциям СМИ. Я.Н. Засурский, Е.В. Вартанова, С.М. Гуревич и другие исследователи признают, что медиасфера стала сферой бизнеса, где действуют прежде всего законы экономики, а целеполагающим является получение прибыли.

1990-е гг. - это время потери достигнутого в советский период уровня вещания для детей, а также усиления негативного воздействия телевидения на социализацию личности в целом [Шариков, Чудинова, 2007, с. 58]. Продолжается расформирование единой системы телевещания для детей, выходит крайне мало образовательных передач.

В это время детские редакции получают автономию. Дети сталкиваются с засильем рекламы и агрессией на телевизионных каналах (не рассчитанных на их возраст). Начинается интенсивное внедрение импортной продукции на ТВ с целью развлечения аудитории. Вместе с тем формируется телевизионный рынок и растет конкуренция телеканалов.

В начале 1990-х гг. стартовал новый период развития российского ТВ, когда западная, в основном американская, популярная культура (музыка, телесериалы, мультсериалы и кинематограф) постепенно приобретает широкую массовую распространённость, а иностранные телеканалы получают ротацию в нашей стране.

\section{Проблемы постсоветского детского телевидения}

В настоящее время крупнейшие транснациональные корпорации создают контент, привлекающий огромную детскую аудиторию, руководствуясь, прежде всего, законом коммерции. Западная телепродукция, нацеленная на развлечение, несет в себе и определенный ценностный заряд, ее продвижение в контексте глобализации стирает черты наци- 
онального самосознания новых поколений, поскольку национальные культуры подменяются глобализационной массовой культурой.

С разрушением Советского Союза традиции советского детского телевещания были почти утрачены, и становление современного российского детского телевидения происходило медленно и проблемно. В результате в детском вещании образовался своего рода вакуум [Аношина, 2003].

На проблемы постсоветского детского телевидения обращали внимание и в научной среде. Многие исследователи отмечали негативное влияние процессов коммерциализации ТВ на детей. Социологи А.В. Шариков и В.П. Чудинова [2007] отметили социализирующую роль телевидения и рассмотрели его проблемы: телепоказ перенасыщен криминалом и насилием, чисто развлекательными программами. Анализируя ценностную составляющую передач, исследователи отмечают информационную вседозволенность телевидения, то есть отсутствие морально-нравственных «табу». В 1990-е гг. законодатели и исполнительные органы власти в России перестали решать на законодательном уровне вопросы безопасности телевидения для юных зрителей.

На фоне отсутствия российских специализированных детских телеканалов незанятая ниша начинает заполняться каналами для детей, принадлежащими транснациональным корпорациям.

Кризис детского телевещания описывает исследователь И. Аношина в статье «Все лучшее - дядям?», отмечая, что все три ведущих телеканала страны на детских новогодних каникулах в 2003 году «вышли из ситуации одинаково - заполнив эфир однообразной по содержанию и формам детской видеопродукцией: в основном американскими и отечественными мультфильмами, семейными комедиями производства США и детскими фильмами советских времен» [Аношина, 2003].

В своем комментарии «Телевидение - для зрителей, или зрители - для ТВ?» А. Короченский подмечает, что «телевизионная индустрия работает главным образом на себя, а не на зрителя. Именно поэтому традиционное представление о том, что телевидение служит для информирования и просвещения маленьких зрителей, а уже потом и развлечения, явно не стыкуется с практикой ведущих российских каналов» [Короченский, 2003].

Усвоение ценностей, социальных норм, правил поведения задается в экранной культуре с помощью образов, создаваемых режиссерами, сценаристами, художниками, артистами и другими создателями передач, фильмов, текстов. С точки зрения исследователей [Шариков, Чудинова, 2007], по сравнению с советским периодом в этой сфере произошло много негативных изменений. Одной из важнейших функций телевидения, по В.С. Собкину [Собкин и др., 2000], является обеспечение социально-интеграционного единства, и эту функцию телевидение к 2000-м годам практически не осуществляло.

Под давлением растущего общественного неодобрения и медиакритики к 2007 году на законодательном уровне ставится вопрос о создании отечественного тематического канала для детей и юношества при участии государства. Его необходимость продиктована дефицитом качественного детского контента, преодолению которого должно было способствовать государственное вмешательство, так как частный бизнес не проявлял интереса к детскому вещанию из-за существовавшего тогда запрета транслировать коммерческую рекламу в передачах для детей.

25 июня 2009 года вступил в силу Указ от 24.06.2009 № 715 «Об общероссийских обязательных телеканалах и радиоканалах», подписанный президентом РФ Дмитрием Медведевым. В документе было зафиксировано решение правительства РФ о создании телеканала для детей младшего возраста «ТелеНяня» (на базе ОАО «Первый канал») и канала для подростов «Бибигон» (в составе ВГТРК). Позже, в 2011 году, оба канала были объединены в один федеральный телеканал «Карусель», который стал общедоступным. Офи- 
циально основной аудиторией провозглашаются дети от 3 до 18 лет, но фактически зрителями становятся дети от 3 до 13 лет.

Последние десять лет развитие отечественного телевидения для детей ознаменовалось открытием нескольких дециметровых каналов (Школьник, Детский, Дисней, Ник Джуниор и др.). Этому способствовала отмена запрета на трансляцию коммерческой рекламы в передачах для детей. На законодательном уровне сформулированы требования и квоты эфирного времени по ограничению рекламы в детских передачах. Эти нормы содержатся в Законе о СМИ и Законе о рекламе.

Но многие проблемы не устранены: на экране по-прежнему мало образовательных и развивающих программ, много вопросов вызывает преимущественно развлекательный уклон передач и их сомнительное аксиологическое наполнение. Быстрый рост производства программ не сопровождается их высоким качеством, большая часть контента «американизирована» по стилю и содержанию. Зарубежный коммерческий опыт формирования содержания телепрограмм для детей игнорирует отечественные, воспитательные, культурные традиции, которые зачастую отвергаются организаторами телепроизводства как избыточные, дорогостоящие [Маховская, 2017, с. 3]. В итоге сохраняется угроза негативного воздействия передач на телезрителей-детей.

О.И. Маховская [2017] отмечает, что психологический контроль детских программ так и не сложился, поэтому необходима модель психологической экспертизы качества телепрограмм для детей, которая должна строиться с учетом теорий и положений возрастной, педагогической и социальной психологии, теорий и концепций базовых парадигм психологической науки, что предполагает участие психолога, специалиста по детскому развитию, на всех этапах телевизионного производства.

В 2012 году сформулированы требования к экспертизе и классификации информации, в том числе и телевизионной продукции, в федеральном законе «О защите детей от информации, наносящей вред их здоровью, нравственному и духовному развитию».

Отметим, что на развитие детского телевидения также повлияло техническое развитие. Катализатором этого процесса стал интернет, который год за годом наращивал и продолжает наращивать свое влияние на подрастающее поколение.

Основываясь на изучении детского российского ТВ на постсоветском этапе (с начала 1990-х гг)., выделим основные периоды его развития:

1) Период острого кризиса детского телевещания (с 1987-го по 1997 годы). В это время детские редакции закрываются, многие передачи советского времени исчезают из эфира. И только в 1996 году начал транслировать первый специализированный отечественный телеканал «Детский мир». В этот период основной объем детской продукции телевещания покрывался за счет видеосюжетов иностранного производства, например, блоком «Дисней» на ОРТ. Это время проникновения западных телеканалов для детей (Cartoon Network, Nickelodeon) на российский телевизионный рынок. Становление детских телеканалов. Время многочисленных проблем для детского информационного контента: насилия на экране, коммерциализации, манипулятивной информации.

2) Период иностранной интервенции (с 1998 по 2005 годы): Ниша детского вещания заполнена транснациональными (американскими) телеканалами для детей, идет распространение специализированных развлекательных детских транснациональных каналов (американского телебизнеса): Nickelodeon (1998), Cartoon Network (1998), Fox Kids Play (2003). Одновременно происходил спад трансляций детских передач российского производства на эфирных каналах, так как детская аудитория не привлекательна для рекламодателей.

3) Начало реабилитации российского детского ТВ (2005-2010 гг.). Появляются новые отечественные детские телеканалы, такие как «Детский» (2006), и зарубежные Cartoon Network (2005). В 2006-2007 годах стартовали российские каналы «ТелеНяня» и «Бибигон», «Ракета ТВ»- прототипы телеканала «Карусель», а также иностранные Boom- 
erang (2003), Jim Jam (2008), Kids Co. Появились телеканалы французско-американской транснациональной корпорации Television Limited Lagardere (Tiji d, 2009 and Gilligirl, 2016) и британской Chellomedia (Zone Jim Jam, 2009).

Названный период - это время функционирования государственного федерального российского детского ТВ и развития отечественных детских телеканалов. С 27 декабря 2010 г. действует «Карусель» - государственный федеральный общедоступный российский детский телеканал с бесплатным доступом. Это период прогрессирующей активности «медийного поколения» и развитие детского телевещания в России как на иностранных, так и на отечественных каналах. Появляются крупнейшие игроки информационного детского рынка в российском информационном пространстве помимо Карусели - DisneyChannnel, Мульт, Nick Jr. Период характеризуется повышением технического качества трансляций и переходом на форматы высокой четкости (HD). Контент стал более разнообразным, предназначенным для детей разного возраста, расширилась тематика телеканалов.

В последние годы наблюдается увеличение аудитории детского ТВ и медийной активности маленьких детей. Интернет и планшеты становятся для детей главными средствами медиапотребления наряду с телевидением. В эти годы телеканалы стали более активными в интернет-пространстве. Под влиянием цифровых технологий и интернета развиваются и меняются технологические и технические качества российского детского ТВ (цифровизация, интерактивность, диджализация и др.). Наблюдаются рост и типологического многообразия телеканалов и программ.

В наши дни популярность контента и телевидения для детей растет с каждым днем.

За прошедшие 10 лет в российском детском телевидении произошли перемены. На сегодняшний день действуют более 40 детских телеканалов, почти все являются платными кабельными с небольшой аудиторией. Позитивной тенденцией является увеличение российских детских телеканалов, в их числе «Карусель», «Мульт», «О!», «Мультимузыка» и другие. Появляется много детского контента, в том числе и образовательного. С устранением ограничений на рекламу производство детских программ и мультфильмов стало выгодным бизнесом. Однако при этом редакторы зачастую забывают о воспитательной роли детского контента.

Сейчас на детском телевидении происходит трансформация жанров. В сетке вещания некоторых из детских каналов все же в небольших количествах представлены спортивные, музыкальные, художественно-изобразительные, научно-популярные, патриотические передачи.

C внедрением цифровых технологий в России улучшается техническое оснащение телевидения для детей, расширяется зона покрытия вещания. Но все же содержание детских программ не дотягивает до советского уровня по нравственно-воспитательному компоненту и до западного - по качеству технологий. В итоге до настоящего времени сохраняется дефицит качественного отечественного телевизионного продукта для российских школьников и подростков.

Все еще огромное влияние на детскую аудиторию имеют транснациональные каналы, принадлежащие компаниям «Time Warner», «Walt Disney Company», «Viacom», и имеющие различные языковые вариации по всему миру, включая Россию.

Государство все чаще участвует в поддержке детских телеканалов, но делается это не всегда успешно. Постепенно возрастает запрос на обучающие и развивающие детские программы. Общественность также стремится влиять на развитие детского сегмента телевещания. Так, в последние годы пользователи создали портал «Научи хорошему» и направили петицию президенту с требованием большей поддержки ТВ для детей. Непрофессиональные коммуникаторы принимают участие в создании детского видеоконтента, размещаемого на Ютуб (так, например, создан музыкальный проект «Кукутики», в котором дети в костюмах зверей поют незатейливые песенки на фоне мультяшных декораций. 


\section{Выводы}

Выделены два этапа отечественного детского телевидения: советский и постсоветский. Периоды советского этапа (появление и развитие советского детского вещания в СССР): 1) зарождение (с 1939 по 1954 гг.); 2) создание системы советского детского вещания (1954-1970 гг.); 3) подъем советского детского кинематографа и передач для детей (с 1970 г. до середины 1980-х г.); 4) перестроечный» период советского телевещания для детей (1985-1987 гг.). Периоды постсоветского этапа: (становление российского детского ТВ): 1) ПЕРИОД острого кризиса в детском телевещании (с 1987 по 1997 гг.); 2) период интервенции западных телеканалов (1998 по 2005 гг.); 3) начало реабилитации отечественного детского ТВ (с 2005 по 2010 гг.); 4) период функционирования государственного федерального российского детского ТВ (с 2010 года по настоящее время).

Отечественные основы создания детских образовательных и развлекательных передач были заложены на советском этапе детского телевещания с 1939 по 1990 год. Современное российское детское телевидение отличает создание первого детского телеканала (1996 г.), затем телеканала «Карусель» и приобретение им общедоступного статуса (2011 г.); появление и представление продукции качественного собственного детского контента цифрового телевидения, создание собственных современных передач, мультфильмов для их последующей трансляции по детским каналам.

Рассмотренная периодизация в данном исследовании свидетельствует о возможной преемственности в развитии отечественного телевещания для детей, в практике современного ТВ для детей может использоваться позитивный опыт советского телевидения. Необходимо тщательно продумывать направленность детского контента, совмещая опыт советского телевещания и современные подходы, включая зарубежные, воссоздать вектор развития детского телевещания с освоением советского опыта создания воспитательных и познавательных передач. Также нужно решить вопросы регулирования рекламы на детских телеканалах и развития медиаграмотностности юных телезрителей.

Отечественное телевидение для детей, испытавшее сильнейший кризис в 1990-е годы, понемногу реабилитируется и восстанавливается уже на коммерческой основе. Сегодня происходит технико-цифровая трансформация детского телевидения. В последние годы у детской аудитории отмечена популярность, наряду с телевидением, интернета, благодаря растущей доступности планшетов, мобильных телефонов как главных средств медиапотребления в современном обществе. Это требует концептуального пересмотра воззрений на технологическую базу и формы современного телевещания для детей.

С учетом происходящей ныне тотальной коммерциализации и глобализации необходимы дальнейшие исследования, вносящие вклад в анализ и развитие детского телевидения в России.

\section{Список источников}

1. Аношина И. 2003. Все лучшее дядям? Детские программы на российском TB. URL: https://tv-digest.ru/archive/id/1313/ (дата обращения: 10.04.2020)

2. Благовещенская A. 2002. Что мы делаем со своими детьми? Независимая газета. URL: https://www.ng.ru/education/2002-05-16/10_children.html (дата обращения: 12.04.2020)

3. Георгиевская М. 2019. ADINDEX. Детское медиапотребление. Что интересно юной аудитории в интернете и на TB. URL: http://momri.org/2019/newsaboutmomri/mediaprofi-detskoemediapotreblenie-chto-interesno-junoj-auditorii-v-internete-i-na-tv/ (дата обращения: 19.03.2020)

4. Дети. Медиапотребление. 2017. Отчет MOMRI. 2018. URL: http://cyberpsy.ru/articles/children_media_2017_momri/ (дата обращения: 01.04.2020).

5. Егоров В. 1997. Терминологическоий словарь телевидения: основные понятия и комментарии. URL: http://evartist.narod.ru/text2/09.htm (дата обращения: 15.03.2020) 
6. Короченский А. 2003. Телевидение - для зрителей, или зрители - для TB? URL: https://tv-digest.ru/archive/id/1313/ (дата обращения: 10.04.2020)

7. Мультимедийный контент. Business-text.com. 2019. URL: http://businesstext.com/blog/vse-o-kopiraytinge/multimediyniy-kontent_(дата обращения: 17.04.2020)

8. Развитие детского ТВ в России. Часть 2. 2015. URL: https://www.cableman.ru/article/razvitie-detskogo-tv-v-rossii-chast-2 (дата обращения: 02.04.2020)

9. Российские дети и медиа. 2018. URL: https:/telesputnik.ru/materials/tsifrovoetelevidenie/article/rossiyskie-deti-i-media/ (дата обращения: 05.04.2020).

10.Роткевич Е. 2018. Детям стали показывать рекламу на TB как взрослым. URL: http://gorod-812.ru/detyam-stali-pokazyivat-reklamu-na-tv-kak-vzroslyim/ (дата обращения: 10.04.2020)

11.Советская печать в документах. 1961. М., Госполитиздат, 559 с.

12.Танаев К. 2018. Об особенностях детского медиапотребления. URL: https: //telesputnik.ru/materials/tsifrovoe-televidenie/video/kirill-tanaev-momri-ob-osobennostyakh-detskogomediapotrebleniya/ (дата обращения: 10.04.2020)

\section{Список литературы}

1. Гук А.А. 2014. История любительского кино-, фото- и видеотворчества. Кемерово, КемГУКИ, 39 с. URL: https://rucont.ru/efd/278199 (дата обращения: 26.06.2020).

2. Залевская Е.Н. 2009. Критический анализ передач современного детского телевидения (российские телеканалы «Теленяня» и «Бибигон». В кн.: Современная журналистика: тенденции и особенности развития. Сборник материалов Международной научно-практической конференции, г. Москва, 24-25 декабря 2009 года. М., Институт гуманитарного образования и информационных технологий: 246-253.

3. Ильченко С.Н. 2009. Отечественное телевидение на рубеже столетий. СПбГУ, Изд-во СПбГУ, 468 с.

4. Качкаева А.Г. 2000. Российские средства массовой информации, власть и капитал (к вопросу о концентрации СМИ в России). В кн.: Правовое регулирование концентрации и прозрачности СМИ. Под ред. Г. В. Винокурова, А. Г. Рихтера, В. В. Чернышова. М.: 30-100.

5. Ключевская О.С. 2019. Детское телевидение в России в исторической ретроспекции и на современном этапе. В кн.: Медиачтения СКФУ. Материалы Третьей Международной научнопрактической конференции, г. Ставрополь, 23-25 мая 2019 года. Под ред. О.И. Лепилкиной, А.М. Горбачева, Н.Н. Борисенко, Д.А. Шевцовой. Ставрополь, Сервисшкола: 119-122.

6. Маховская О.И. 2017. Дети и телевидение: История психологических исследований и экспертизы телепрограмм для детей. Под ред. О. И. Маховской, Ф. О. Марченко. Москва, ИНФРА$\mathrm{M}, 171 \mathrm{c}$.

7. Мыгаль М. 2014а. Детское телевидение в контексте современной культуры. В кн. Международная журналистика-2014: диалог культур и взаимодействие медиа разных стран. Материалы третьей международной научно-практической конференции, г. Минск, 20 февраля 2014 года. Под ред. Т.Н. Дасаевой. Минск, Изд. центр БГУ: 204-214.

8. Мыгаль М.С. 2014б. Программная политика детских каналов в России: особенности распределения телевизионного контента в сетке вещания, жанрово-тематический состав, целевая аудитория. Научные ведомости БелГУ. Серия: Гуманитарные науки,13 (184), вып.22: 223-233.

9. Собкин В.С, Хлебникова М.В., Грачева А.М. 2000. Насилие и эротика на российском экране: опыт контент-анализа телевизионных трансляций. В кн.: Образование и информационная культура: социологические аспекты. Труды по социологии образования. T. V. Вып. VII. Под ред. В. С. Собкина. М., Центр социологии образования РАО: 138-161.

10. Федоров А.В., Челышева И.В. 2002. Медиаобразование в России. Краткая история развития. Таганрог, Изд-во «Познание», $266 \mathrm{c.}$

11. Холод А.Я. 2017. «Кино-газета» (1929-1931 гг.) и освещение проблемы воспитания детей с помощью кинопродукции того времени. В кн.: Дискурсология и медиакритика средств массовой информации. Сборник научных работ по материалам научно-практической конференции, г. 
Белгород, 4-7 октября 2017 года. Под ред. А.В. Полонского, М.Ю. Казак, С.В. Ушаковой. Белгород, ИД «Белгород» НИУ «БелГУ»: 34-46.

12. Шариков А.В., Чудинова В.П. 2007. Детское телевидение. Взгляд социолога. В кн.: Дети и культура. Под ред. Б.Ю. Сорочкина. М., КомКнига: 58-85.

13. Цвик В.Л. 1997.Телевидение переходного периода (тенденции и проблемы реформирования в условиях информационного рынка). Автореф. ... дисс. докт. филол. наук. М., 47 с.

\section{References}

1. Guk A.A. 2014. Istoriya lyubitel'skogo kino-, foto- i videotvorchestva [History of amateur film, photo and video creation]. Kemerovo, Publ. KemGUKI, 39 p. Available at: https://rucont.ru/efd/278199 (accessed: 26.06.2020).

2. Zalevskaya E.N. 2009. Kriticheskiy analiz peredach sovremennogo detskogo televideniya (ros-siyskie telekanaly «Telenyanya» $\mathrm{i}$ «Bibigon» [Critical analysis of modern children's television programs (Russian TV channels "Telenyanya" and "Bibigon"]. In: Sovremennaya zhurnalistika: tendentsii i osobennosti razvitiya [Modern journalism: trends and features of development]. Sbornik materialov Mezhdunarodnoy nauchno-prakticheskoy konferen-tsii, Moskva, 24-25 dekabrya 2009 goda. M., Institut gumanitarnogo obrazovaniya i informa-tsionnykh tekhnologiy: 246-253.

3. Il'chenko S.N. 2009. Otechestvennoe televidenie na rubezhe stoletiy [Domestic television at the turn of the century]. SPbGU, Publ. Izd-vo SPbGU, 468 p.

4. Kachkaeva A.G. 2000. Rossiyskie sredstva massovoy informatsii, vlast' i kapital (k voprosu o kontsentratsii SMI v Rossii) [Russian mass media, power and capital (on the issue of media concentration in Russia)]. In: Pravovoe regulirovanie kontsentratsii i prozrachnosti SMI [Legal regulation of media concentration and transparency.]. Eds. G.V. Vinokurov, A.G. Rikhter, V.V. Chernyshov. M.: 30-100.

5. Klyuchevskaya O.S. 2019. Detskoe televidenie v Rossii v istoricheskoy retrospektsii i na sovremennom etape [Children's television in Russia in historical retrospection and at the present stage]. In: Mediachteniya SKFU [Media readings of NCFU]. Materialy Tret'ey Mezhdunarodnoy nauchno- prakticheskoy konferentsii, g. Stavropol', 23-25 maya 2019 goda. Eds. O.I. Lepilkina, A.M. Gorbachev, N.N. Borisenko, D.A. Shevtsova. Stavropol', Publ. Servisshkola: 119-122.

6. Makhovskaya O.I. 2017. Deti i televidenie: Istoriya psikhologicheskikh issledovaniy i ekspertizy teleprogramm dlya detey [Children and Television: A History of Psychological Research and Examination of Television Programs for Children]. Eds. O. I. Makhovskaya, F. O. Marchenko. Moskva, Publ. INFRA-M, $171 \mathrm{p}$.

7. Mygal' M.S. 2014a. Detskoe televidenie v kontekste sovremennoy kul'tury [Children's television in the context of modern culture]. In: Mezhdunarodnaya zhurnalistika-2014: dialog kul'tur i vzaimodeystvie media raznykh stran [International Journalism 2014: Dialogue of Cultures and Interaction of Media of Different Countries.]. Materialy tret'ey mezhdunarodnoy nauchno-prakticheskoy konferentsii, g. Minsk, 20 fevralya 2014 goda. Ed. T.N. Dasaeva. Minsk, Publ. Izd. tsentr BGU: 204-214.

8. Mygal' M.S. 2014b. Programmnaya politika detskikh kanalov v Rossii: osobennosti raspredeleniya televizionnogo kontenta $\mathrm{v}$ setke veshchaniya, zhanrovo-tematicheskiy sostav [Program policy of children's channels in Russia: features of the distribution of television content in the broadcasting network, genre and thematic composition, target audience]. Scientific bulletin of Belgorod State University. Humanities Sciences,13 (184), Iss. 22: 223-233.

9. Sobkin V.S, Khlebnikova M.V., Gracheva A.M. 2000. Nasilie i erotika na rossiyskom ekrane: opyt kontent-analiza televizionnykh translyatsiy [Violence and Erotica on the Russian Screen: Experience of Content Analysis of Television Broadcasts]. In: Obrazovanie i informatsionnaya kul'tura: sotsiologicheskie aspekty [Education and information culture: sociological aspects]. Trudy po sotsiologii obrazovaniya. Vol. V. Iss. VII. Ed. V.S. Sobkin. M., Publ. Tsentr sotsiologii obrazovaniya RAO: 138-161.

10. Fedorov A.V., Chelysheva I.V. 2002. Mediaobrazovanie v Rossii. Kratkaya istoriya razvitiya [Media education in Russia. A brief history of development]. Taganrog, Publ. Izd-vo «Poznanie», 266 p.

11. Kholod A.Ya. 2017. «Kino-gazeta» (1929-1931 gg.) i osveshchenie problemy vospitaniya detey s po-moshch'yu kinoproduktsii togo vremeni ["Kino-Gazeta" (1929-1931) and coverage of the problem of raising children with the help of film products of that time]. In: Diskursologiya i mediakritika 
sredstv massovoy in-formatsii [Discourseology and media criticism of mass media]. Sbornik nauchnykh rabot po materialam nauchno-prakticheskoy konferentsii, Belgorod, 4-7 oktyabrya 2017 goda. Eds. A.V. Polonskogo, M.Yu. Kazak, S.V. Ushakova. Belgorod, Publ. ID «Belgorod» NIU «BelGU»: 34-46.

12. Sharikov A.V., Chudinova V.P. 2007. Detskoe televidenie. Vzglyad sotsiologa [Children's television. Sociologist's view]. In: Deti i kul'tura [Children and culture]. Ed. B.Yu. Sorochkin. M., Publ. KomKniga: 58-85.

13. Tsvik V.L. 1997. Televidenie perekhodnogo perioda (tendentsii i problemy reformirovaniya $\mathrm{v}$ usloviyakh informatsionnogo rynka) [Television in transition (trends and problems of reforming in the information market)]. Abstract ... diss. doct. philol. sciences. M., 47 p.

\section{ИНФОРМАЦИЯ ОБ АВТОРЕ}

Ключевская Олеся Сергеевна, аспирант кафедры журналистики института общественных наук и массовых коммуникаций Белгородского государственного национального исследовательского университета г. Белгород

\section{INFORMATION ABOUT THE AUTHOR}

Olesya S. Klyuchevskaya, Postgraduate student, Department of Journalism, Institute of Social Sciences and Mass Communications, Belgorod State National Research University, Belgorod 